\title{
Kuning in karo Community: Medical Anthroplogy Study in Bunuraya Village, Tiga Panah District, Karo Regency
}

\author{
Roseva Sari Br Bangun and Sabariah Bangun \\ Departmen Ilmu Antropologi Sosial, Universitas Sumatera Utara, Indonesia \\ Rosevasari5@gmail.com
}

Key words: Traditional Herbs, Kuning, Karo

Abstract: This research discusses the cultural heritage of one of the ethnic groups in Indonesia, such as the new traditional medicine, namely Kuning. The purpose of this study is to describe the presence of Kuning in the Karo community and its benefits for the community so that it is maintained as one of the traditional Karo medicines. This research is a descriptive type with a qualitative approach. The method used in data collection is occasional participatory observation and interviews, the baseline information is the village head, the key information is traditional leaders and people who have lived in Bunung Raya for a long time, from the usual information is the Kuning maker and the Kuning user. The result of Kuning's research is that traditional Karo medicine made from a mixture of various herbs has fewer negative side effects when compared to modern medicine and is more economical in its manufacture.

\section{INTRODUCTION}

The goal of health development is to increase the community's ability to live healthy and be able to overcome health problems, especially through prevention and improvement. In order to make health services evenly accessible to people in remote areas, traditional medicine is an appropriate alternative to accompany modern medicine efforts. Traditional medicine and traditional medicine have been used by the community in overcoming various health problems both in rural and urban areas (Azwar Agoes, 1992: 12).

One of the main problems that need attention is the problem of public health. Health is very important for human survival because without a healthy body, humans will not be able to meet all their needs. Therefore, every human being wants to live a healthy life. A healthy body is a condition where the members of the body as a whole can carry out their functions as they should. Humans do various ways to get a healthy body, both modern and traditional (Mustika. 2017).

The World Health Organization or WHO stated in 1977 that public health services cannot be evenly distributed without including traditional medicine. Traditional medicine with traditional medicines has a cultural background in the community and can be classified as appropriate technology because the ingredients used are around the community itself so that they are easy to obtain, cheap, and easy to use without requiring expensive equipment to prepare them (Azwar Agoes, 1992: 60).

This is also seen by almost part of Indonesian society, when they are sick they try to treat themselves with traditional methods or traditional (alternative) medicine. If they are not successful then they go to medical service places or (modern) doctors. Sometimes there are people who use both treatments (Trisnawan. 2015).

According to the Ministry of Health of the Republic of Indonesia, modern medicine is a drug derived from chemical or synthetic materials using modern equipment. Modern medicine is based on the results of research through scientific principles. Modern medicine serves to prevent, eliminate, reduce and cure a disease (Zalmi. 2009).

Indonesia is the second natural biodiversity country in the world after Brazil. The use of medicine comes from any plant that is foreign to the Indonesian society in which they are located. Even some ethnopharmacology studies already exist in various tribes in Indonesia. Indonesian people have a lot of symplisia medicinal plants and extracts of plants in the form of herbal medicine (Tjandrawinata, 2020).

People prefer to use natural medicines from plants to cure diseases because chemical drugs often have negative side effects so that the body becomes unhealthy. Therefore, chemicals are not good for the body so that the drug is often called a poisonous drug. Another reason is that modern medicine has not been able to effectively cure diseases and the 
high price of drugs is due to the high cost of drugs and medicinal raw materials (Savitri. 2016).

Based on the weaknesses of these chemical drugs, currently the concept of returning to nature in the field of disease treatment and health care is increasing. There are several advantages of medicinal plants, although their use is less practical, namely that they do not have side effects and the price of drugs is cheaper because some medicinal plants can be planted independently in the yard and in the natural environment, it is also reinforced in the study of Uma, 2021 that medical treatment tends to require a small cost and time, in contrast to alternative treatments that offer low costs and short treatments as well as without side effects (Uma, 2021).

Awareness of the above facts, the use of medicinal plants is accepted by the community as traditional medicine and a natural and safer way to maintain health. Traditional medicine is considered by the community as an effort to cure disease and a way of maintaining health that is safer than modern medicine. The side effects of traditional medicine are less than modern medicine because the ingredients used in the manufacture of traditional medicines come from nature.

According to the Ministry of Health of the Republic of Indonesia, traditional medicine is medicine derived from plant, animal, mineral or a mixture of these ingredients. Based on the knowledge of the ancestors, customs, beliefs that are passed down from generation to generation. Traditional medicine has not been scientifically proven because its use for health is based on experience. The use of medicinal plants aims to cure disease, prevent disease, and maintain body condition

People in the modern era do not fully believe in scientific medical treatment. Each group of people who believe in medicine and alternatives has different good in between. In truth today, the development of modern medical medicine practices both within government and private institutions is always accompanied by traditional medicine practices. It is desired that traditional medicine that still lives becomes an alternative model in society (Fanani, 2014).

Medicine or tambar (in Karo language) is Karo medicine as a history that continues to grow and comes from many sources. There are medicines that are passed down from ancestors, there are from dreams, and the results of one's own observations in everyday life. There is also a medicine written by the ancestors in the skin or laklak wood called pustaka laklak kayu or pustaka najati (Ginting E P, 1999: 52).
This nutritious plant has long been used by the ancestors and gives good results in the treatment of diseases and health maintenance. Over the centuries many plants have medicinal properties for various diseases. In ancient times, people knew about medicinal plants and how to use them as medicine. The source of that knowledge comes from ancestors or parents.

Parts of medicinal plants that can be used as ingredients in the manufacture of traditional medicines are roots, stems, leaves, flowers and fruit. Traditional medicines are still owned and believed by the Karo people to this day, including: Kuning, plain, oilseeds or massage oil, spray, and oukup or steam bath. One of these traditional medicines would like to be studied in depth. As for what wants to be the focus of this research is Kuning (Tarigan, 2010).

Treatment with herbs usually use herbs in the form of roots, leaves, stems, fruits from plants that are categorized as medicine by the community. In addition to plant materials also use animal materials and other natural minerals. Treatment in the form of actions such as sorting (alun), summoning the soul (kicik / raleng tendi), mantra (tabas-doa), tingling (semburi), using oil (erminak), sticking the herb (erdampel), anggih (drops), erpangir (berlangir), erkuning (wearing yellow), oukup (steam bath), and surungi (smearing the smoothed herb). While the combined treatment pattern is to perform treatment actions and eat / drink the herb (Sembiring, 2015).

Kuning is a traditional Karo medicine made from a mixture of flour and ingredients that have medicinal properties. The flour that is usually used is rice flour because the Karo people believe that rice is a symbol of staying healthy and cheap fortune. Potions that have medicinal properties are ingredients or mixtures of plants such as roots, stems, leaves, flowers, fruit and animal fats as well as water.

The importance of traditional medicinal ingredients for the Karo people can be seen from the use of these traditional medicines in everyday life. In general, the Karo people who live in the village always provide traditional Karo medicine. The people of Karo believe that traditional Karo medicine is very useful for maintaining endurance or improving health.

Bunuraya village still finds people who are good at making Kuning. People who are good at making traditional medicines in Bunuraya Village are called by the community as bidders or penambar. The bidder is a person who has the knowledge to make traditional Karo medicines in Kuning or param and bargain forms. People who work as farmers, after one day of working in the fields, will use Kuning to warm their bodies. 
A new mother also uses Kuning in the morning and evening to keep her body healthy and strong. Kuning is also used on newborns by the mother so that her child will grow up healthy and strong. People who are in the process of healing disease use Kuning based on the recommendation of the Kuning maker.

The benefits of Kuning have been felt by researchers themselves. Since attending Junior High School, researchers often come to Bunuraya Village with their parents to visit the family home. For example, at annual parties and other family events. At night researchers use Kuning to warm the body and prevent colds. The above causes the researcher to conduct a descriptive study regarding the presence of Kuning in the Karo community in Bunuraya Village.

\section{RESEARCH METHOD}

This research is descriptive in nature, which describes accurately the nature of an individual, a certain condition or relationship between a phenomenon in society. The method in this research is a qualitative research method, from the results of the research it produces descriptive data in the form of written or spoken words to know the perpetrators who can be observed (Moleong 2005: 4).

This study has three types of informants, namely base informants, main informants or keys and ordinary informants. There are two base informants in this study, namely the Head of the village and the village secretary, key informants who have expertise regarding a problem that exists in the community and which is of concern. Ordinary informants are people who provide information about a problem according to their knowledge.

The data collected in this study are primary data and secondary data, primary data is data obtained from the field using data collection techniques from observations, interviews. While secondary data is data to complement primary data obtained from literature studies, chemistry, internet, research results related to research problems.

\section{RESULT AND DISCUSSION}

Traditional medicine is the result of the culture that is owned by each ethnic group which is passed on from one generation to the next. Karo traditional medicine in the Karo community is called tambar kuta (village medicine). Tambar kuta or village medicine is the result of the Karo culture passed down from our ancestors from generation to generation.

There are several types of traditional Karo medicines, among others: param (kuning), kusuk oil (minak alun), spray, and steam bath (oukup). Kuning is a traditional Karo medicine made from a mixture of flour and ingredients that have medicinal properties. The kuning discussed here is hot kuning to warm the body, cold kuning for medicine for fractures, sprains, swollen and sore body parts, blood circulation, lowering heat, kuning for itching medicine, kuning for good luck to get offspring, kuning offer for fever medicine, kuning pinakit mulajadi for congenital diseases such as constipation, frequent urination at night, and fever or high fever, kuning colds, and kuning gout.

Based on its nature, kuning is divided into 2, namely: 1 hot kuning (Kuning melas), and: 2 kuning which is cold (kuning dingin). There are 2 categories of kuning based on the wearer, namely: 1 kuning for children (kuning danak-danak) and: 2 kuning for adults (kuning kalak galang). There are 5 kuning categories based on its benefits, namely: 1 kuning for itching (kuning sogo-sogo),: 2 kuning for getting offspring (kuning fruit), 3 kuning for reducing fever or heat (kuning tawar mbulan) ,: 4 kuning for cold medicine (kuning masuk angin), and: 5 kuning for gout medicine (kuning Asam rat).

The categories of Kuning herb ingredients are divided into 6, among others: 1 . Terrestrial Kesaya (ingredients that can be found in the natural environment, 2. Kesaya-kesaya Tiga (ingredients that are traded in traditional markets), 3. Bulungbulung (plant leaves), 4. Sinuan-sinuan flower (plant flower), 5. Sinuan-sinuan fruit (plant fruit), and 6 . sinuan-sinuan stem (plant stem) Some of the tools used in making kuning are machetes, knives, slicing places. Kuning herb, a place to boil kuning potions, mills, mortar, tampi, a place to store kuning made of woven pandan leaves, pestle, and bamboo for roasting kuning, cut, squeezed, and baked.

How to use kuning is smeared (ikuningken) and eaten (pan) or drunk (inem). The time to use kuning is in the morning and at night. The places used to store kuning are chopsticks, ndiru (tampi), aqua bottles and jars, and reeds (bamboo).

The belief in the kuning herb ingredients as one of the traditional Karo medicines is considered to have strengths, among others: removing disease, fighting disease, avoiding bad things that can interfere with health, curing illnesses, teaching illness, fending off disease, cleaning disease, and giving strength in the face. disease. Faith in the amount of kuning herb ingredients, namely: unite against disease, keep the spirit in the flesh even in a state of illness, scratch the disease, prevent disease from coming back, avoid disease, seek disease, and 
excrete disease. Belief in the method of taking the kuning herb, namely: removing disease, cutting disease so that it is cut off from the body, and deciding disease.

Faith in the method of making kuning, namely: cleaning disease, grinding disease, pounding disease, squeezing disease, slicing disease until it is released from the body, and boiling disease germs in the body so that it does not develop. Belief in how to use kuning, namely: treating diseases from the outside of the body and healing diseases from the inside of the body. Faith in the storage area of kuning, namely: pressing the course of the spread of disease in the body, getting rid of disease, and killing disease.

Kuning as one of the traditional Karo medicines is useful in curing diseases and caring for body health. In addition, kuning has a social function in everyday life in Karo people. The social function in question is that kuning is often used as a luah or gift. When visiting mothers who have just given birth, they usually bring Karo traditional medicines such as kuning, spray, and massage oil. There are also people who visit to give a little money as a sign of being happy about the birth of the baby so that it is used to buy the newborn's kuning.

Marketing of the traditional Karo medicine, namely kuning, is done by informing the benefits of kuning from one person to another. In other words, there is no patent right or production permit from the government due to lack of attention from the government in terms of traditional health. Karo and the public also do not understand about the license to produce drugs in the health sector. This is also caused by the lack of cooperation between traditional and modern medical treatment.

\section{CONCLUSION}

Kuning as one of karo traditional medicine is useful in curing diseases and taking care of the health of the body. In addition, Kuning has a social function in daily life in karo people. The social function in question is Kuning is often used as a luah or gift. At the time of visiting the mother who has just given birth is usually brought karo traditional medicine such as Kuning, tinge, and kusuk oil. There are also people who visit to give a little money as a sign of joy over the birth of the baby to be used to buy the Kuning of the newborn. Marketing of karo traditional medicine that is Kuning is done by informing the benefits of yellow from one person to another. In other words, the absence of patents or production permits from the government due to the lack of attention from the government in terms of traditional health Karo and the public also do not understand about the production permits of medicines in the field of health. This is also due to the lack of cooperation between traditional medicine and modern medicine.

\section{REFERENCES}

Agoes Azwar-Jacob T. 1992. Indonesian Health Anthropology. Medical Book Publisher. Jakarta.

Fanani, S., \& Dewi, T. K. (2014). Health belief model pada pasien pengobatan alternatif supranatural dengan bantuan dukun. Jurnal psikologi klinis dan kesehatan mental, 3(1), 5459.

Ginting, E.P. 1999. Religi Karo. Abdi Karya. Kabanjahe.

Harianja, A. H. (2012). Faktor-faktor yang Mempengaruhi Komsumsi Tumbuhan Obat Dari Hutan Konservasi dari Kabupaten Karo, Sumatera Utara. Jurnal. Parapat: Balai Penelitian Kehutanan Aek Nauli.

Moleong Lexy, J. 2006. Qualitative Research Methods. PT. Remaja Rosdakarya Offset. Bandung.

Mustika, Y. (2017). Fenomena Pengobatan Tradisional Di Desa Cempedak Lobang Kecamatan Sei Rampah Kabupaten Serdang Bedagai (Doctoral dissertation, UNIMED).

Savitri, A. (2016). Tanaman Ajaib! Basi Penyakit dengan TOGA (Tanaman Obat Keluarga). Bibit Publisher.

Sembiring, S. (2015). Pengetahuan dan pemanfaatan metode pengobatan tradisional pada masyarakat Desa Suka Nalu Kecamatan Barus Jahe. Perspektif Sosiologi, 3(1), 156771.

Tarigan, A. A. (2010). Pelaksanaan Hukum Waris pada Masyarakat Karo Muslim di Kabupaten Karo (Doctoral dissertation, IAIN Sumatera Utara Medan).

Tjandrawinata, R. R. (2020). Konsep Obat Modern Asli Indonesia (OMAI) dalam penggunaannya di fasilitas kesehatan formal. https://www.academia.edu/download/63430483/ Konsep Obat Modern Asli Indonesia.pdf

Trisnawan, P. D. (2015). Determinan Perilaku Pencarian Pengobatan Pada Mahasiswa Fakultas Kedokteran Dan Ilmu Kesehatan UIN Syarif Hidayatullah Jakarta

Uma, A. M. (2021, January 27). Faktor kepercayaan Masyarakat terhadap pengobatan Medis dan Alternatif. https://doi.org/10.31219/osf.io/7sph2

Zalmi, H., Gemasih, M. I. S., \& Rahmadani, A. (2019). Jenis Jenis Obat-Obatan Dan Manfaatnya Bagi Mahkluk Hidup. https://doi.org/10.31227/osf.io/z7tf2 